\title{
SMUG1 Gene
}

National Cancer Institute

\section{Source}

National Cancer Institute. SMUG1 Gene. NCI Thesaurus. Code C150319.

This gene is involved in the initiation of DNA base excision repair. 